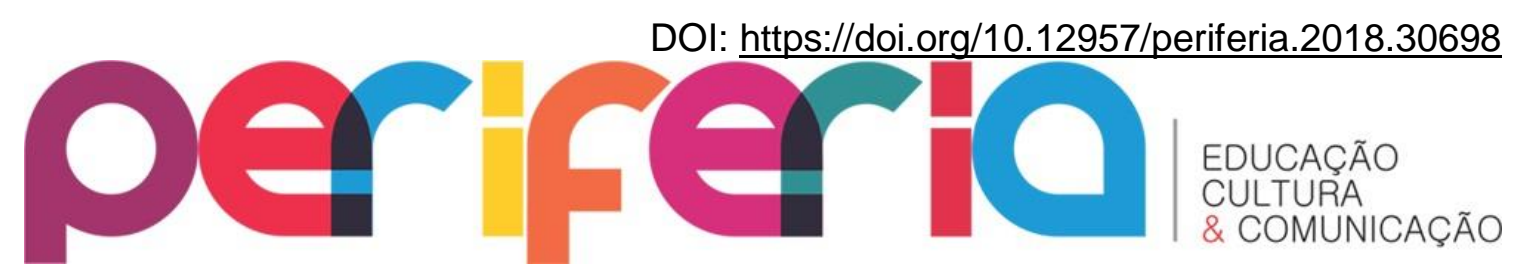

\title{
OUTROS NEGROS
}

Ademir Barros Santos ${ }^{1}$

Resumo: Este artigo busca apresentar, em contraponto à voz oficial, outras posturas das negritudes transpostas compulsoriamente para o Novo Mundo, visto que os meios oficiais, ainda hoje, enfatizam a dominação pacífica do europeu sobre o africano que, no extremo, ainda é visto, mesmo, como conivente com o processo. Portanto, é necessária a constante vigilância sobre o contínuo e persistente apagamento da ação dos movimentos culturais e sociais que os próprios negros produziram, instrumentalizando a cultura nacional à procura de caminhos para própria libertação. É com este intuito que esta análise se dispõe a discorrer sobre a evolução dos processos de enfrentamento à dominação europeia ocorrida no Brasil, com ênfase na ininterrupta resistência cultural que, ao final, permitiu a sobrevivência dos saberes de matriz africana em suas diversas formas e nuances, inclusive como instrumentalizadora da sociedade nacional, o que se torna evidente ainda nos dias atuais. Este o ponto e objetivo do que vai aqui exposto.

Palavras-chave: Diáspora africana. Resistência cultural. Africanidades.

\section{The other blacks}

Abstract: In contrast to the official voice, this article seeks to present other positions of the black power, which was compulsorily transposed, to the New World, since the official media, even today, emphasize the peaceful domination of the European over the African, who in the extreme is still seen as conniving with the process. Therefore, constant vigilance is needed over the continuing and persistent erasure of the cultural and social movements that the black people themselves have produced, exploiting the national culture in search of ways to liberate itself. With this objective, the present analysis is willing to discuss the evolution of the processes of confronting the European domination which happened in Brazil, with emphasis on the uninterrupted cultural resistance that, in the end, allowed the survival of the knowledge of African matrix in its various forms and nuances, including as an instrument of national society, which is still evident today. This is the point and purpose of what is presented here.

Keywords: African diaspora. Cultural resistance. Africanities.

\section{INTRODUÇÃO}

Para início, deve-se lembrar que o maior movimento migratório registrado pela

\footnotetext{
1 Mestrando em Educação pela Universidade Federal de São Carlos. Coordenador da Câmara de Preservação Cultural do Núcleo de Cultura Afro-Brasileira da Universidade de Sorocaba
} 


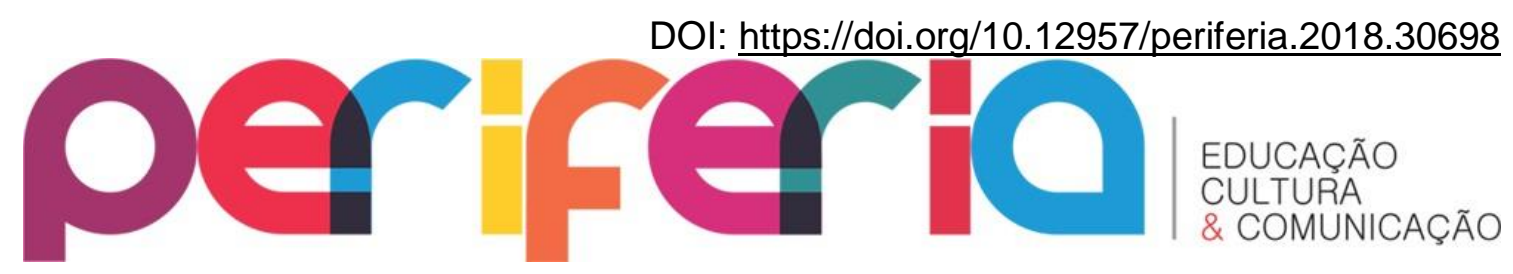

história da humanidade envolve, pelo menos, dez milhões de emigrantes involuntários, deportados, com extrema violência, do continente africano para as Américas, onde se viram condenados, sem qualquer crime, a sevícias e trabalhos compulsórios.

No tempo, o processo tem início em meados do séc. XV; no século seguinte, incrementa-se com a descoberta das Américas, estendendo-se até o final do séc. XIX.

No espaço, atinge todas as populações do litoral atlântico do continente negro, onde se encontravam três culturas principais: Alta Guiné, Baixa Guiné e África Central; deste espaço, quinze milhões de africanos são, estimadamente, vitimados pelo processo de transferência compulsória, dos quais algo em torno de dez milhões desembarcam; o restante, simplesmente não resiste à violência que lhes foi aplicada; quarenta por cento de todo o contingente chegado vivo, foi alocado ao Brasil!

É assim que o povo negro, despersonalizado e descivilizado, expurgado de suas sociedades e culturas de origem, animalizado, desconhecedor dos costumes e idiomas em que é recebido, sendo destinado, apenas, ao trabalho mais vil, compulsório e sob tortura... sobrevive!

Nas senzalas. Mas, sobrevive.

\section{Senzalas: as oficinas de Exu}

Segundo define Lopes (2004), o termo aproximado "sanzala", em quimbundo, significa "habitação de indivíduos da mesma família"; para Slenes (1999, p. 148) o termo, atualizado, traz a conotação de "residência de serviçais em propriedade agrícola"; ou, ainda, "povoado".

É possível que, na diáspora, o significado apontado por Lopes tenha se generalizado mais e, a partir de então, tenha adquirido o signifcado que Slenes aponta.

Sobre o tema, ensina Moura (1989, p. 7-8):

Esta história começa com a chegada das primeiras levas de escravos vindos da África. Isto se dá por volta de 1549 , quando o primeiro contingente é desembarcado em São Vicente. D. João III concedeu autorização a fim de que cada colono importasse 120 africanos para as suas propriedades. [...] alguns historiadores acham que bem antes dessa data já haviam entrado negros no Brasil. Afirmam mesmo que na nau Bretoa, para aqui enviada em 1511 por Fernando de Noronha, já se encontravam negros a bordo. 


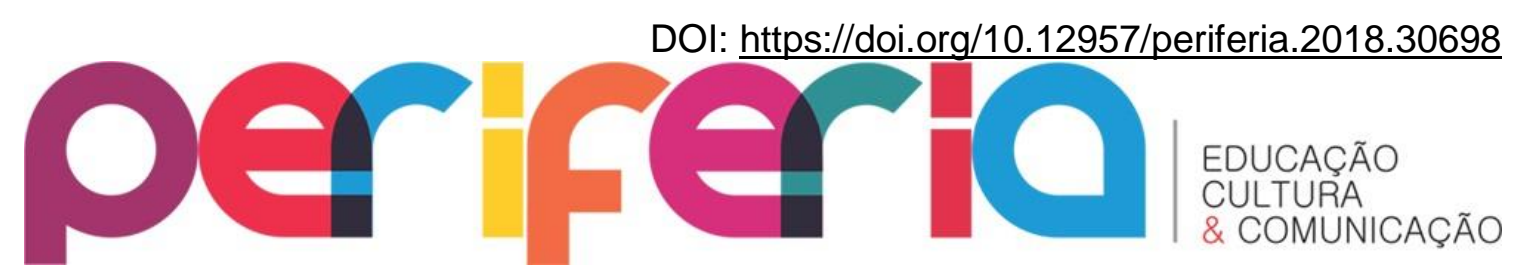

Uma vez no eito brasileiro, o escravizado recebia tratamento de animal de carga e tração, de tal forma que Moura (1989, p. 17) aponta: "a jornada de trabalho era de catorze a dezesseis horas, sob a fiscalização do feitor, que não admitia pausa ou distração".

Então prossegue ele à mesma página, informando que, em contrapartida a essa jornada e "conforme a falta, havia um tipo de punição e de tortura. Mas a imaginação dos senhores não tinha limites, e muitos criavam os seus métodos e instrumentos de tortura próprios”.

Cabe citar: a partir de 1741, o Estado autoriza, por alvará, que se marque, com ferro em brasa, um " $F$ " na testa do escravo fugido; aos reincidentes, podia-se cortar a orelha; não produzindo efeito o castigo, cabia a pena de morte!

É evidente que o que acima vai descrito leva a pensar que o negro senzalado, conformado com sua sorte de escravo ou com medo do castigo, se colocava como subalterno e, consequentemente, tornava-se apático, não encontrando nenhuma forma de resistir.

Se engana quem pensa assim: afinal, com quantas espinhas negras forçadamente curvadas, viu-se feita e erguida a coluna cultural de nosso povo? Quem sabe um dia, pelo menos algumas das costelas apoiadas naquelas espinhas pretas entortadas, vejam suas fraturas um tanto quanto remendadas, mesmo que apenas toscamente, a partir de então.

Primeiro, é preciso ressala que, mesmo naquele ambiente hostil, o fenômeno asociativo se manifesta: tendo em vista que ambientes hostis incentivam a formação de associações informais, quer para mútua ajuda, quer como facilitadoras de negociações políticas e de lazer, não é difícil imaginar a necessária união de malungos ${ }^{2}$ para a composição daquelas, nestes agressivos locais.

É de se admitir, até por pura lógica, que africanos que partilhavam culturas mais próximas no ambiente de origem, formassem os primeiros grupos de ajuda informal; afinal, o compartilhar cultura lhes permitia partilhar estratégias e soluções comuns para problemas também comuns.

Como corolário, o incontornável ambiente da senzala partilhada pode ter estendido as soluções encontradas por um grupo, mesmo que por imitação, para os demais grupos, também covitimados pela mesma desgraça senzalada.

\footnotetext{
${ }^{2}$ Amigos, em tradução ampla e livre.
} 


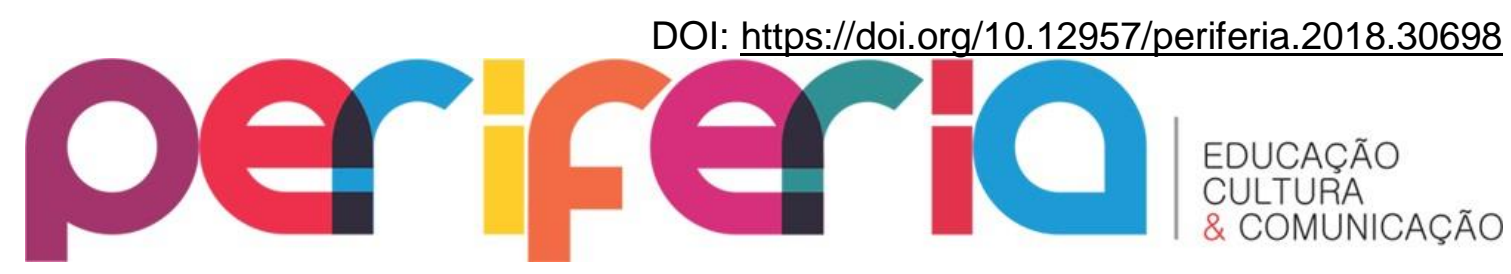

Por decorrência, é destas toscas formações novas que resulta a cultura afroamericana, inexistente na África: pessoas de diversa origem se encontram e trocam, negociam e se autoapoiam compulsoriamente, permutando informações, posições, crenças e idiomas e, consequentemente, reformatando tudo o que sabiam, agora amalgamado em formas mais confortáveis, que se desenvolviam continuamente, no dia a dia.

Assim a oficina de Exu, orixá que desmancha o que está pronto para que coisas novas, nascidas do que foi desmanchado, aconteçam; portanto, é da vitória do Deus Cristão, deus da ordem, contra Exu, o deus da desordem, que talvez se tenham amoldado novas formas afroamericanas, transformando-se em coisa outra, nova mas antiga, mesmo sem perder o que trazia de ancestral.

\section{Escravos novos}

Para a obtenção de escravos novos, a formação de famílias nas senzalas americanas, exceto no século final do processo escravista, era algo praticamente impossível: importava-se algo em torno de oito homens por mulher, visto que a escravidão tinha, por finalidade primeira, o trabalho braçal, extenso e forçado, para o qual as mulheres, assim como as crianças e os velhos, não formavam, evidentemente, o contingente mais indicado.

Porém, há que se atentar que, destas senzalas e das poucas mulheres de início para cá trazidas, nasceram outras, permitindo, ao longo do tempo, a produção de crioulos, quer a partir de africanas natas, quer de crioulas já aqui nascidas.

Quanto à reprodução natural entre escravizados, é Ribeiro (1995, p. 163) quem opina talvez com certo exagero - quando fala das mulheres:

A negra-massa, depois de servir aos senhores, provocando às vezes ciúmes em que as senhoras lhes mandavam arrancar todos os dentes, caíam na vida de trabalho braçal dos engenhos e das minas em igualdade com os homens. Só a esta negra, largada e envelhecida, o negro tinha acesso para produzir crioulos.

Porém, Slenes (1989) detecta modificações de comportamento ocorridas no final do período escravista; isto, especialmente após a Inglaterra iniciar o combate ao tráfico, o que torna o translado escravista um risco; e caro.

Ao analisar dados de registro de escravos na região do Médio Tietê, produzidos a 


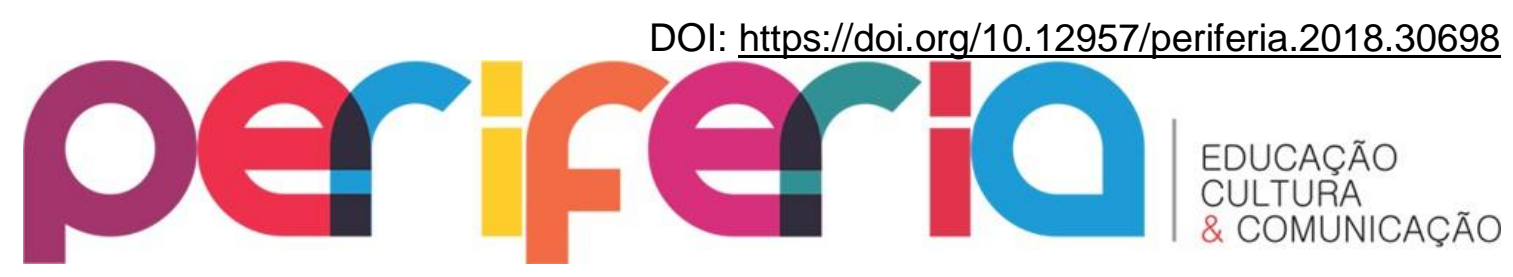

partir do início do séc. XIX - batismos, casamentos, inventários e similares - aponta ele para a existência de famílias consistentemente mantidas; assim, por exemplo, a tabela que estampa à p. 98 daquele seu estudo, referindo-se à Campinas de 1872:

\begin{tabular}{ccc}
\hline $\begin{array}{c}\text { Idade de } \\
\text { escravas-mães }\end{array}$ & Quantidade & Tempo de casamento \\
\hline $15-24$ & 9 & 3 anos e 03 meses \\
$25-34$ & 25 & 11 anos e 06 meses \\
$35-44$ & 14 & 16 anos e 11 meses \\
\hline Totais e média & $\mathbf{4 8}$ & $\mathbf{1 1}$ anos e 7 meses \\
\hline \hline
\end{tabular}

Por necessário, informe-se que as tabelas que utiliza, segundo informa, não registram uniões consensuais: limitam-se aos casamentos efetivamente celebrados pela Igreja Católica; por final, Slenes ainda apresenta (1989, p. 102), atestando a permanência e estabilidade das famílias no final do período escravista, o percentual de legitimidade dos filhos de escravas: Campinas, $1872 \rightarrow 80 \%$ !

Parece claro que, pelo menos ao final do séc. XIX, quando o processo escravista estava terminando e o casamento entre escravos passa a ser possível e até incentivado, é contestável a informação corrente, que aponta promiscuidade desmedida entre escravos, nas senzalas...

\section{Quilombos}

Quanto à propalada postura conformista do escravo com sua situação de coisa de uso, animal que fala, depõe a instituição do quilombo que, segundo ensina Munanga (1996), é palavra cuja origem aponta para o umbundu, idioma do povo ovimbundu: isso porque a raiz "-lombo", neste idioma da família bantu, refere-se, com certeza, ao ritual da circuncisão; porém, entre este ritual e a formação de estruturas de resistência ao processo escravista, há longa história, modificando o significado e alcance do termo.

Isto é: um dos mais arraigados e difundidos costumes africanos é o ritual de iniciação dos jovens que, somente a partir dele, deixam de ser considerados crianças, iniciando vida adulta; nele ritual, a circuncisão é o momento mais importante para os homens que, antes dela, são tratados como assexuados e, só a partir de então, ficam aptos para o casamento. 


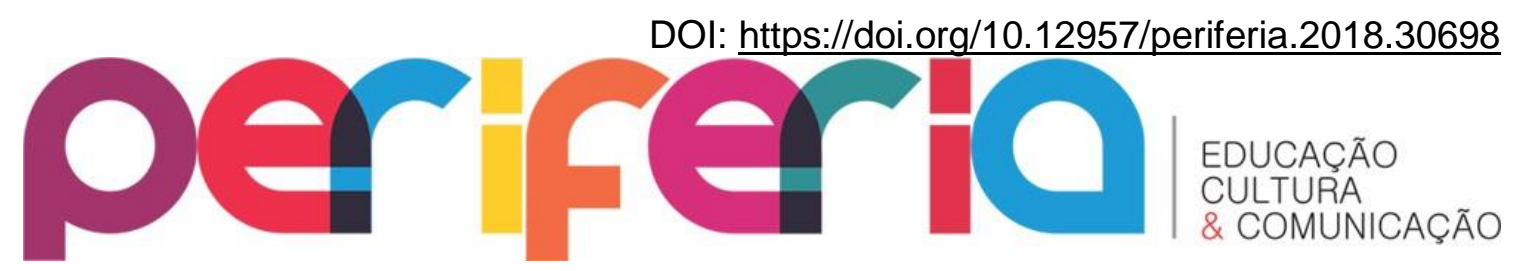

É neste ponto que é necessário voltar a atenção aos jagas - ou imbangala - e seus rituais de iniciação.

O povo jaga, ou imbangala

Vindos da margem direita do rio Cuango, os imbangala - cujo nome, segundo Munanga (1996), parece derivar da raiz umbundu “-vangala", que significa "ser bravo" e/ou "vagar pelo território" - invadiram o Congo, de onde, em 1568, foram rechaçados; porém, portando vínculos culturais com os lunda e os luba, misturaram-se a grupos suku, organizando numerosas chefias; essencialmente guerreiros, quando chegam ao oeste do rio Cuango, vivem em campos fortificados e em permanente pé de guerra.

Um dos seus costumes mais típicos era a incorporação ${ }^{3}$, à sua sociedade, de jovens retirados dos povos por eles vencidos e dominados: assim, o tamanho de suas tropas aumentava rapidamente, o que explica, em parte, sua superioridade militar frente a seus inimigos; isto, de tal forma que imprimiram sua marca na história angolana durante meio século!

Para essa mencionada incorporação, realizavam eles rituais voltados a desvincular os jovens de suas linhagens de origem, incorporando-os ao próprio grupo, como se ali houvessem nascido; e este ritual era realizado em seus campos sagrados de iniciação, os quilombos.

Quanto ao transporte deste instituto para as Américas escravistas, Munanga e Gomes (2006, p. 72) ensinam:

O processo de aquilombamento existiu onde houve escravidão dos africanos e seus descendentes. Em todas as Américas há grupos semelhantes, porém, com nomes diferentes, de acordo com a região onde viveram: cimarrónes em muitos países de colonização espanhola, palenques em Cuba e Colômbia, cumbes na Venezuela e marroons na Jamaica, nas Guianas e nos Estados Unidos.

Vê-se, claramente, que a instituição quilombo, até por sua conotação política, é forte

\footnotetext{
${ }^{3}$ Via de regra os jagas, até por seu impressionante poderio guerreiro, eram vistos, por seus inimigos, como espíritos invencíveis; com isto em mente, parece inteligível a atração dos jovens das tribos vencidas por sua incorporação aos exércitos jaga; talvez se possa entender esta atitude por comparação às incorporações voluntárias às hostes, por exemplo, do ainda hoje lendário Virgolino Lampião.
} 


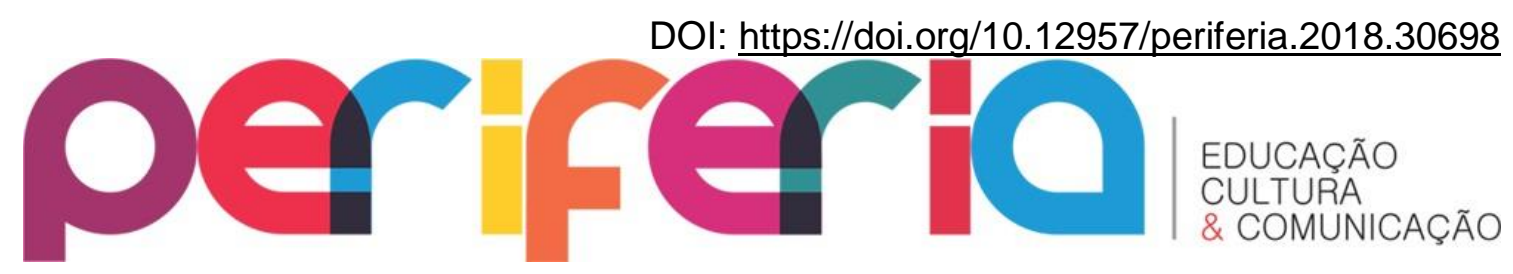

geradora de instituições sociais, que acabam por se disseminar por todo o Novo Mundo.

Evidentemente, há diferenças entre os dois formatos; porém, surpreende, mesmo, a identificação de conteúdos; se, na África, o quilombo jaga era liderado pelo guerreiro entre guerreiros, chefe pouco transigente dentro da rigidez da disciplina militar, não é diferente no Brasil: mesmo quando subdividido em aldeias ou mocambos, estes se reportavam à liderança central, gerida pelo guerreiro dos guerreiros - em Palmares, primeiro Ganga Zumba; depois, Zumbi.

Se, na África, o quilombo era multiétnico, tendo claras finalidades político/militares, assim também no Brasil: todos os fugidos do sistema que para lá se dirigiam, encontravam abrigo nesta instituição, cuja finalidade sociopolítica - escapar, opondo-se à estrutura dominante - torna-se sua própria razão de ser.

Portanto, parece possível deduzir-se que a instituição quilombo configura o módulo mais representativo de resistência à escravidão, quer por seu alcance territorial, quer por sua longevidade; para além, importa o sentimento político que despertou: isto porque a formação de quilombos não foi fenômeno geograficamente localizado, mas acompanhou, clandestino, todo o processo escravista, o que leva Moura (1989, p. 24) a ensinar:

O quilombo foi [...] a unidade básica de resistência do escravo. Pequeno ou grande, estável ou de vida precária, em qualquer região onde existia a escravidão, lá se encontrava ele como elemento de desgaste do regime servil. O fenômeno não era atomizado, circunscrito a determinada área geográfica [...]. O quilombo aparecia onde quer que a escravidão surgisse [...]. Muitas vezes surpreende pela capacidade de organização, pela resistência que oferece; destruído parcialmente dezenas de vezes e novamente aparecendo em outros locais [...]. O quilombo não foi, portanto, apenas um fenômeno esporádico. Constituía-se em fato normal da sociedade escravista.

Portanto, o quilombo não pode ser visto de forma estreita: lugar de negros fugidos, resultado de fugas inconsequentes, apenas; ele foi resistência, e feriu o processo oficial de utilização de mão de obra, de tal forma e com tanta intensidade que, segundo Moura (1989, p. 25) "solapou as suas bases em diversos níveis - econômico, social e militar", influindo decisivamente, "para que esse tipo de trabalho entrasse em crise".

Ressalte-se: a partir de 1835, em que acontece a Revolta dos Malês, o Brasil passa a assistir à morte lenta da escravidão que, em 25 de março de 1884, vê o Ceará expurgá-la de seu território; meses depois, Amazonas e Rio Grande do Sul o acompanham; no campo 


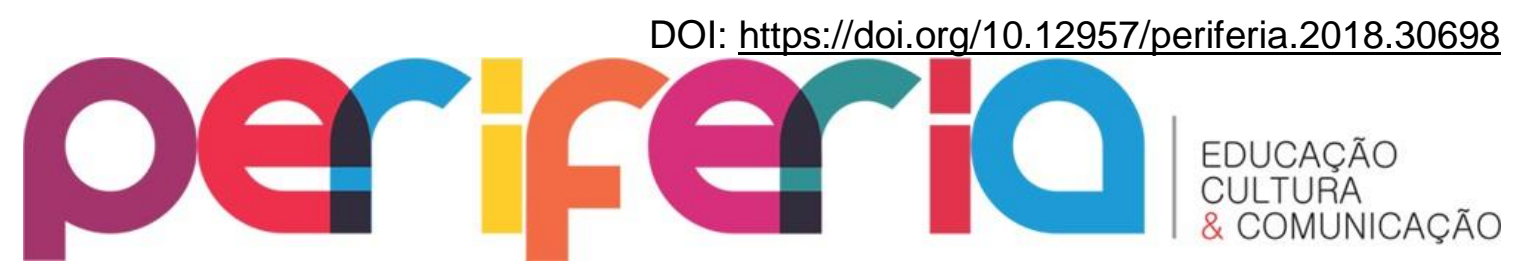

político, Rui Barbosa e Joaquim Nabuco, dentre outros, ecoam o que José do Patrocínio e seus pares pregam pelos jornais e pelas esquinas politizadas da capital e das províncias do país.

É neste ambiente em ebulição que surgem os chamados quilombos abolicionistas, dos quais Leblon, no Rio de Janeiro, e Jabaquara, em São Paulo, são os representantes principais; sobre o tema, eis o que ensina Silva (2003, p. 11):

A crise final da escravidão [...] deu lugar ao aparecimento de um modelo novo de resistência, o [...] quilombo abolicionista. No modelo tradicional de resistência à escravidão, [...] a tendência dominante era a política do esconderijo e do segredo de guerra.

Porém, o quilombo abolicionista deixa de ser lugar de esconderijo, apenas: fartamente conhecido, passa a desafiar, acintosamente, a ordem constituída; isto, por se apoiar na própria estrutura legal, onde estão seus mentores e mantenedores.

Como exemplo, o Quilombo do Jabaquara: fundado em 1882, é comandado pelo negro Quintino de Lacerda ${ }^{4}$, futuro vereador em Santos; estabelecido naquela cidade, o quilombo é mantido por colaborações de comerciantes e simpatizantes, e chega a acolher dez mil pessoas: em sua maioria, fugitivos encaminhados por Antonio Bento e seus Caifazes.

Quanto a Antonio Bento ${ }^{5}$, é abolicionista de família rica de São Paulo, amigo de Luis Gama desde 1882; advogado que chegou a promotor público e, depois, a Juiz de Direito, adota métodos abolicionistas intransigentes, baseados em fugas perfeitamente organizadas por sua "Ordem dos Caifazes"6.

Já o Quilombo do Leblon, fundado na mesma década, formou-se nas terras do bairro que, atualmente, lhe dá nome, onde o português José de Seixas Magalhães, industrial produtor de malas vendidas em todo o país, cultivava camélias que, ao final do processo, se transformaram em verdadeiras insígnias dos abolicionistas - dentre os quais, a Família Real ${ }^{7}$ !

Portanto e à vista da efetiva resistência que os negros, por si, apresentaram ao regime escravista durante todo o período em que este regime vigorou, é forçoso aceitar que a

\footnotetext{
${ }^{4}$ Jabaquara, em tradução livre do tupi-guarani: refúgio, esconderijo; sobre Quintino de Lacerda e a história do quilombo, ver <http://www.novomilenio.inf.br/santos/fotos028.htm>. Acesso em: 06.jun.2006

${ }^{5}$ Ver, dentre outros, <http://pt.wikipedia.org/wiki/Antônio Bento (abolicionista)>. Acesso em: 6 jun. 2006.

${ }^{6}$ Sobre o tema, dentre outros, <pt.wikipedia.org/wiki/Movimento_dos_Caifazes>. Acesso em: 7 jun. 2006.

${ }^{7}$ Ver A carta da Princesa Isabel ao Visconde de Santa Rita, datada de 11.ago.1889. Disponível em:

$<$ http://marconegro.blogspot.com.br/2006/05/polmica-carta-da-princesa-isabel.html>. Acesso em: 2 jul. 2007.
} 


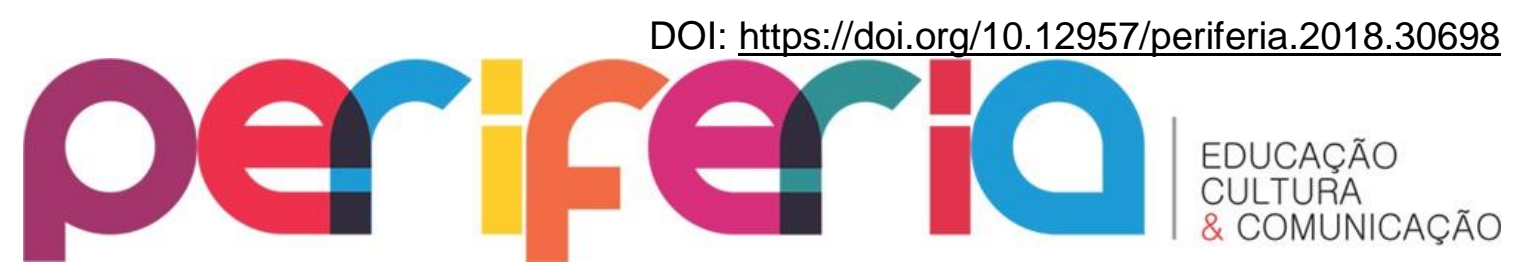

permanência cultural de matriz africana é incontestável na realidade no Brasil atual, malgrado toda a impossibilidade de sobrevivência, física inclusive, que o escravismo impôs aos forçadamente expatriados.

Quanto a estes, mesmo condenados ao exílio ultramarino sem qualquer crime ou justificativa legal, pena agravada pela imposição de trabalhos forçados e sevícias no presídio sem grades do continente americano, encontraram estratégias capazes de manter sua cultura original, mesmo que imperiosamente modificada.

Esta improvável sobrevivência, certamente, deve-se a processos de negociação, dentre os quais se destacam as permanências religiosas, a formação de sociedades leigas, o surgimento de tipos novos e híbridos - os mestiços - e outras formas de resistência e contestação.

Neste processo, há que se atentar, especialmente, para a ação de indivíduos e posturas associativas que, conscientemente ou não, mantiveram aberto o diálogo com os representantes do sistema instituído. Vamos a eles.

\section{A interlocução}

Há que se atentar que, nem sempre, o enfrentamento ao sistema revestiu-se do ódio explícito, do confronto aberto, da guerra surda, da belicosidade, materializada por emboscadas e mortes. Aliás, sempre houve a resistência cotidiana, gota a gota, momento a momento, disfarçada, por vezes, em planos bem pensados, posturas enviesadas, aproximações eivadas de segundas intenções, perfídias ardilosamente dissimuladas, o que comprova, mesmo que por linhas tortas, planejamento e constante oposição do negro ao processo escravista.

Eis, abaixo, alguns dos principais atores deste teatro de horrores.

O escravo urbano

Embora algo em torno de noventa por cento da escravaria africana tenha sido destinada ao pesado trabalho da lavoura ou à extração mineral, parte importante deste segmento obteve melhor destino, permanecendo, já de início, nos incipientes povoados, depois vilas que, por fim, se transformaram em cidades.

Isso porque não se pode negligenciar que a posse de escravos, durante todo o processo, serviu como demonstração de poder, onde o elemento servil era visto como bem de 


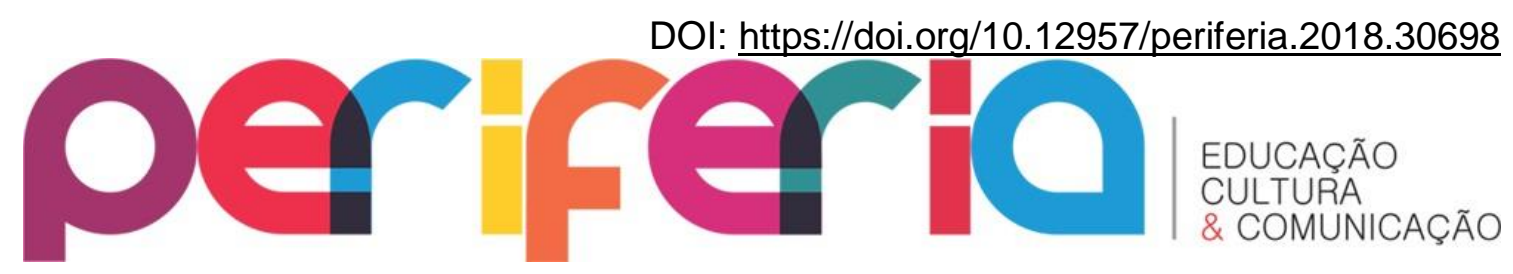

ostentação. Isto posto, é certo que a vida urbana, cuja gênese pode ser encontrada nos vilarejos, onde comerciantes abasteciam as necessidades da Colônia com produtos importados ou locais, não podia prescindir de escravos, necessários ao manuseio da mercadoria comerciada.

Por outro lado os compradores, normalmente vinculados ao latifúndio, também não podiam abrir mão de quem lhes carregasse a capa, a manta, o pacote; ou os transportasse em liteiras, redes e similares, cuidando de cocheiras e cavalos: serviços braçais, indignos do senhor; portanto, trabalhos de escravo.

É evidente que estes escravos, embora em menor número que os de eito, eram constante e consistentemente mais próximos de seus senhores; portanto, tinham-lhes mais acesso à personalidade e tendências, doçuras e azedumes, conhecendo-lhes, de perto, os gostos, prazeres, segredos, amantes e costumes. Do que podiam valer-se para negociar.

Certamente, é entre estes escravos que se deve procurar a melhor adaptação à vida nova em nova terra: por maior convivência com senhores que escravos, maior utilização de costumes europeus que africanos, naturalmente lhes acudia maior rapidez em apreender não só o idioma, como os vícios e manias europeus, de onde deriva a maior facilidade para negociar.

Não se pode esquecer da maior mobilidade, longevidade e trânsito de que dispunham tais escravos, não obrigados ao trabalho de lavoura: por consequência, era-lhes mais fácil o contato com outros escravos de outros senhores, se voltados à mesma atividade - de onde o maior poder de conspiração e associação, quer formal, quer não.

Portanto, reforce-se: é desta matriz que saem, naturalmente, os interlocutores primeiros junto ao sistema; escravizados de cultura mais próxima à de seus senhores, podiam desenvolver - embora servilmente - maior poder de argumentação e, consequentemente, adquirir liderança quando das futuras associações formais de recorte étnico, tais como as confrarias.

A escrava doméstica

Esta produtora forçada de mestiços, diferentemente de sua companheira de senzala, convivia mais próxima de seus senhores: cozinheiras dormiam nas cozinhas, não nas senzalas; amas, ao pé das senhorinhas; assim sendo, obtinham, mais facilmente, benesses junto àqueles 


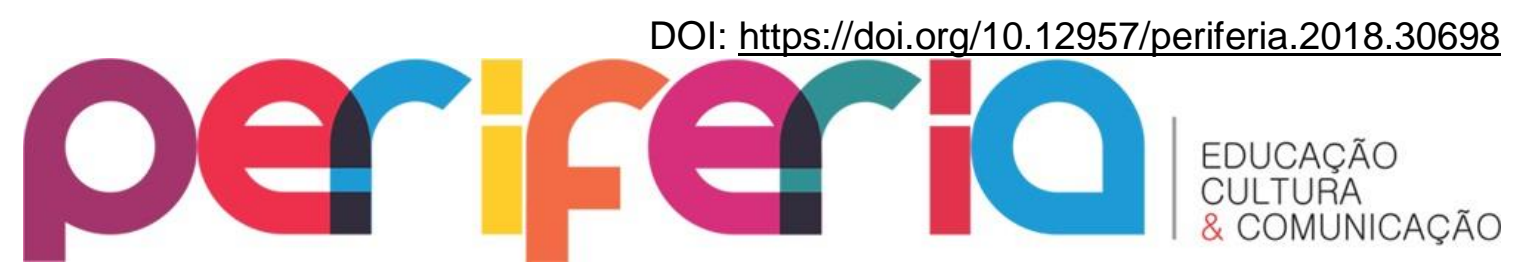

de quem cuidavam e que, necessariamente, lhes conheciam o nome cristão.

Como serviçais caseiras, podiam alimentar-se - mesmo que às escondidas e no recôndito da cozinha - da mesma forma que se alimentavam seus senhores; também podiam atuar como protetoras dos rebentos brancos que, nas cozinhas, refugiavam-se de seus constantemente raivosos pais; ou onde recebiam quitutes ainda não servidos à mesa principal, até porque, a esses, podiam elas adicionar venenos lentos, já conhecidos desde África...

Não se pode esquecer, ainda, da festejada mãe de leite, "mãe preta", cuja estátua espalha-se pelo Brasil afora: estas mulheres estavam, evidentemente, mais próximas de seus "filhos brancos" que, embora seus futuros senhores, nem sempre negligenciavam o cafuné que lhes oferecia o peito que lhes fornecera o leite que haviam mamado.

Desta convivência, é natural, advinha maior poder de negociação do que aquele disponível à escrava de senzala, cuja aproximação da casa-grande só seria possível - exceto raríssimas exceções - para castigos e ordens; ou como objeto de estupros premeditados.

Já à doméstica, também se reservava o estupro; e com maior frequência e facilidade, é claro; até porque - e aí vai a unanimidade entre cientistas sociais, tais como Gilberto Freyre, Darcy Ribeiro, e diversos viajantes - é a esta negra, quase sempre virgem de negro e seminua, que os senhores e seus filhos recorriam para o prazer: à mulher europeia, casada assim que adolescente, restava a produção de prole que, unida às condições adversas da vida na colônia, envelhecia já por volta dos vinte anos.

Esta branca, mal atingidas duas décadas, era encontrada em casa, ociosa e, por isto mesmo, gorda, balofa, suja, mal vestida, tetas murchas, corpo torto e deformado; quanto aos banhos, eram raros: o excesso demonstrava despudor; só os tomava se auxiliada por sua mucama, a quem os banhos costumeiros não eram moralmente proibidos; dentes podres, descalcificados pela interminável gravidez, completavam o quadro, encimado, quase sempre, por perucas sujas e mal arrumadas, meros esconderijos aconchegantes para a infindável piolhada.

Resta que a moral da época, ao vedar às mulheres brancas o prazer do sexo, as transformava, apenas, em objetos frios e imóveis, incapazes de satisfazer a seus maridos.

... e aí vai largo espaço para negociações, do qual negras domésticas, aparentemente, 


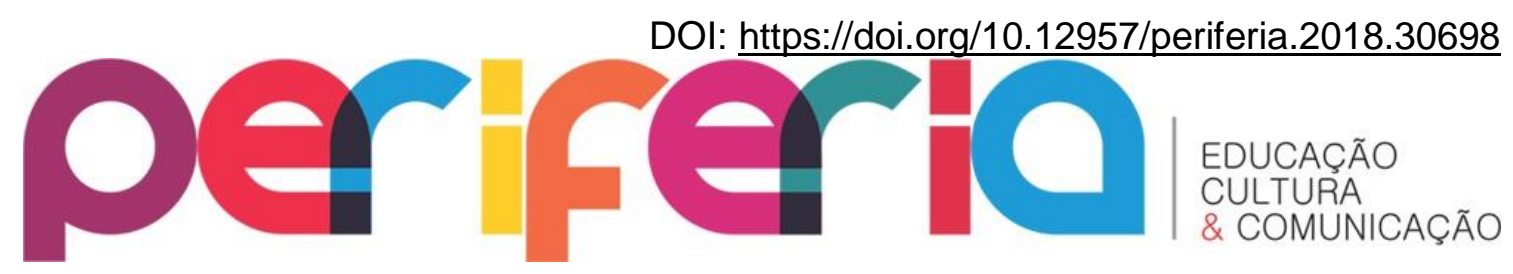

souberam aproveitar-se muito bem; até porque o tempo para tanto poderia não ser longo ${ }^{8}$. Chica da Silva que o diga!

Neste ponto, cabe perguntar: por que as escravas, das quais descendem as negras atuais, buscavam, por vezes, engravidar de seus senhores brancos, pensamento este que tradita para sua mestiça descendência? Seria luxúria nata? Ou, apenas, estratégia de negociação, rápida e passageira, mas constantemente eficaz?

A resposta, mesmo que especulativamente, não parece tão difícil de ser encontrada: diante das condições adversas da escravidão, o filho do senhor, mesmo que futuro escravo, como queria o costume partus sequitur ventrem ${ }^{9}$ poderia, eventualmente, carrear, à mãe, as benesses que o pai nobre, disfarçado de padrinho, eventualmente destinasse ao filho espúrio; daí que à mãe de mestiço, a gravidez poderia ser esperança de boa aposentadoria.

Os mestiços

Da busca da miscigenação que, conforme visto, pode ter partido tanto dos senhores quanto das escravas, restaram falas, tortas e contemporâneas: há muito tempo há quem olhe, ao recém-nascido filho de preto, a cor das orelhas e das cutículas, para adivinhar se não terá pele mais clara que a de seus pais! Pior ainda: em caso positivo, é recorrente dar graças aos céus!

Sobre o tema, eis o que opina Pierson (1976, p. 182, apud Freyre, 1998, p. 60):

A miscigenação é também favorecida pelo prestígio ordinariamente atribuído ao filho "mais branco". As mães de cor, que, na época de nossa pesquisa $^{10}$, tinham filhos "mais brancos" que elas, consideravam-se como especialmente favorecidas e eram da mesma forma consideradas pelos que as rodeavam. Uma preta, mostrando orgulhosamente seu filho claro, disse: "Estou limpando a minha raça". Ouvia-se também na Bahia, frequentemente, a expressão "melhorando a raça".

Na sequência, a eventual ascensão social de poucos pretos entra na conversa, e a exceção vira regra, tornando intransponíveis os argumentos do discurso torto, a derrubar

\footnotetext{
${ }^{8}$ Até porque a mordomia poderia acabar a qualquer momento: quebrar os dentes a marteladas, ou amputar um peito da mucama abusada, nunca foi atitude rara entre senhoras de engenho, movidas por ciúme.

${ }^{9} \mathrm{Em}$ tradução direta, "o parto segue o ventre", ou seja: filhos de mulheres escravas, são escravos; se de mulheres livres, são livres.

${ }^{10} 1935-37$ (nota deste autor).
} 


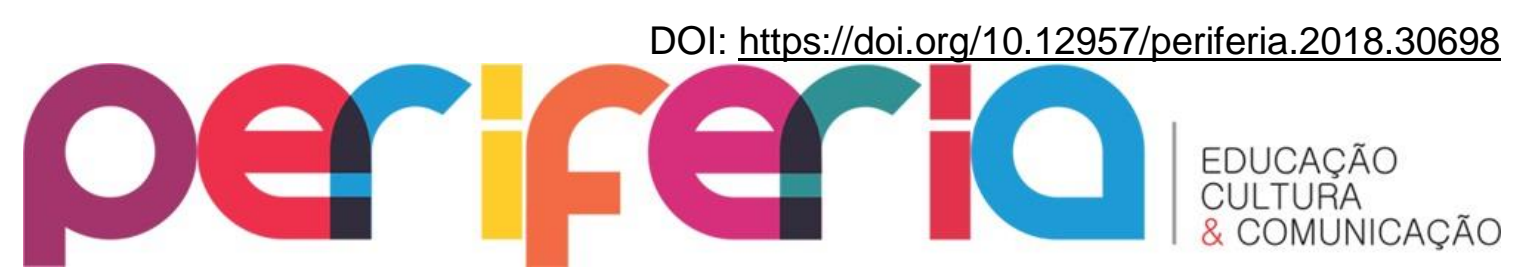

qualquer contestação contrária! Como efeito último, é o próprio mestiço em ascensão social que, por vezes, se contrapõe às reivindicações do povo negro, se mais preto; e utiliza a própria evolução como argumento de combate.

Porém, sua interlocução com o sistema dominante, não pode ser contestada.

\section{Grupos de manutenção cultural}

Se a cultura de matriz africana chega a nossos dias, deve-se a focos socioculturais de resistência e permanência, que não podem ser negligenciados, até por que necessária sua compreensão para a entendimento da atualidade.

Portanto, não é defeso supor que é ao surgimento de núcleos comerciais que se deve o aparecimento das primeiras associações formais de escravos, além dos primeiros interlocutores intersociais.

Isto porque é nestes centros urbanos que se torna possível o encontro de escravos originalmente destinados à vida rural, bem como o aparecimento daqueles tipicamente urbanos. Se não assim, pode-se imaginar que os escravos ficariam confinados nas propriedades rurais em que trabalhavam, o que, infere-se, lhes impediria a formação de associações de maior porte.

Portanto, é nestes centros que escravos de mesma origem podem se encontrar, mesmo quando urbanos ou distribuídos em propriedades rurais diversas; e é destes encontros que surgem tais associações que, no primeiro momento, se formam quase espontaneamente, ao unir os negros, por origem e afinidade.

Neste sentido, há que se enfatizar: para além dos quilombos, outras formas associativas, urbanas e mais pacíficas de resistência cultural se formaram; ei-las.

Irmandades e confrarias

É da cultura africana prender o indivíduo à linhagem, por laços de convivência e solidariedade; isso, tanto aos ancestrais e à descendência, quanto aos pares de mesmo grupo e idade.

Portanto, é a filosofia de matriz africana que assim desenha a sociedade:

- Verticalmente, o indivíduo pertence ao elo da cadeia que vem de seus ancestrais, passa por si e prossegue em sua descendência; 


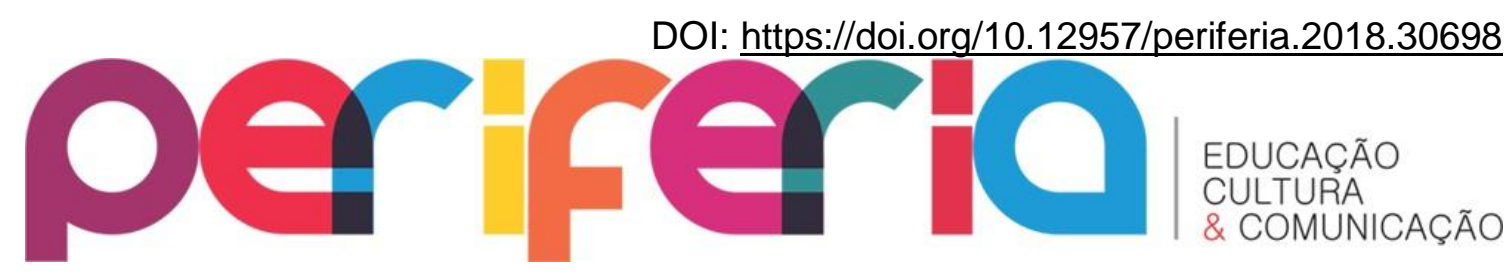

. Horizontalmente, além da incontornável ligação à origem étnica, pertence ele a determinado grupo etário, cuja ascensão o levará, em conjunto e com o simples passar do tempo, de criança a ancião; por fim, a ancestral.

Há, ainda, a solidariedade e companheirismo desenvolvidos pela parceria no mesmo acontecimento significativo que, eventualmente, os une na condição de quase irmãos; como exemplo, a travessia do Atlântico, que passava, a todos, o sentimento de ligação por forças invisíveis, que agiam como laços indestrutíveis, a uni-los no mesmo destino; assim, também e mais constantemente, a senzala; talvez daí o nome "irmandade".

Para materializar a solidariedade, a evolução das associações informais as formaliza, quase sempre com fundo religioso: oficialmente, conforme queriam a Metrópole e os colonizadores, em confrarias, das quais as irmandades são espécie; clandestinamente, no que veio a ser, por exemplo, o candomblé.

Quanto ao tema, Quintão (2002, p. 73) fornece a seguinte explicação:

As confrarias são associações religiosas nas quais se reuniam leigos do catolicismo tradicional. [...] O que caracteriza a confraria é a participação leiga no culto católico. Os leigos se responsabilizam e promovem a parte devocional, sem necessidade de estímulos dos clérigos. Com frequência, a promoção do culto e a organização da confraria se devem totalmente à iniciativa leiga.

No Brasil, formalizadas, além das atividades religiosas, tais como procissões e festas para o santo padroeiro, as irmandades também promoviam festas leigas, tais como coroação de reis e rainhas, além de dedicar-se, necessariamente, à ajuda mútua: daí irmandades como Nossa Senhora da Boa Morte, a responsabilizar-se pelo enterro de seus afiliados, e pela quantidade de missas que, em seu estatuto ou mediante pagamento, deveriam ser rezadas pela alma do morto.

Ressalte-se que a admissão às irmandades importava compromissos dos postulantes, quer quanto à vida social, quer quanto à vida religiosa. Como efeito se, por um lado, pertencer à irmandade conferia status, a exclusão representava, simbólica e socialmente, quase a excomunhão!

Quanto às irmandades de negros, também processaram de nova forma as relações de linhagem: inicialmente buscaram juntar, em seus quadros, oriundos de mesma fonte, quer por 


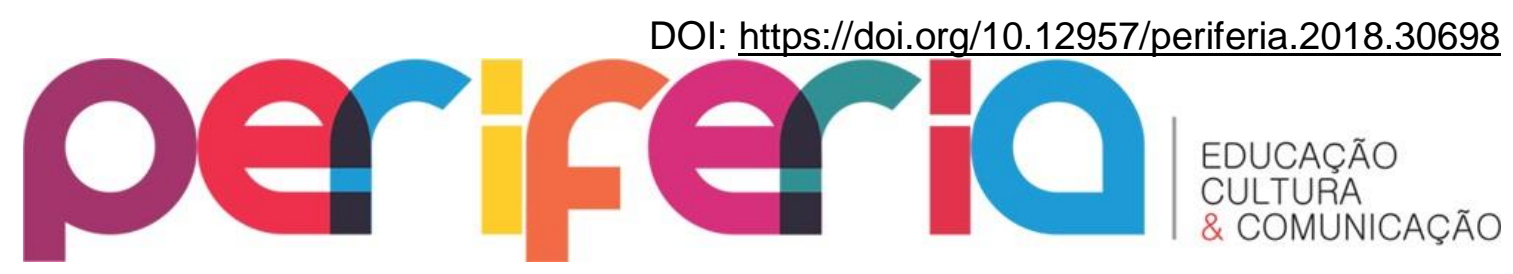

etnia de origem africana - assim, irmandades de jêges, de angolanos, etc. - quer pela cor da pele - irmandades de pretos, de pardos ${ }^{11}$, ou de pretos livres, pardos livres, etc..

Os brancos eram aceitos nas irmandades de negros, até como possíveis interlocutores com a sociedade dominante; porém, era comum negar-lhes a assunção a certos cargos, tais como diretoria ou presidência porque, por certo, imaginavam os negros que os cargos de comando, se delegados a brancos, poderiam descaracterizar a finalidade associativa.

Por outro lado, era comum a preferência de brancos para o preenchimento de cargos administrativos, por razões óbvias: o maior trânsito junto à sociedade dominante e a maior disseminação da alfabetização, fazia postos como o de tesoureiro e secretário destinados, preferencialmente, a brancos.

Parece evidente o espaço privilegiado que as irmandades adquiriram para o diálogo com o clero, formatando o que se pode chamar de "pseudossincretização", que consiste na negociação entre essas partes, já que, vivendo sob a proteção da Igreja, para honrar seus "deuses" africanos, aquelas recorriam ao disfarce de festejar os santos católicos correspondentes.

Na outra ponta, o pároco: voltado à catequese, justificativa primeira para o próprio processo de exportação de africanos, é a ele, então detentor de poder civil e religioso, que se deviam reportar os escravizados para festejar seus orixás; portanto, é necessário e imprescindível, para a estratégia, o encontro de pontos de contato entre as duas religiosidades.

Assim sendo, determinado, pelos negros, o santo católico que encobrirá o orixá, basta apresentar a festa ao clérigo, que autorizará este ou aquele ritual, esta ou aquela roupa, esta ou aquela cor, na festa de celebração do santo escolhido.

Permissão dada, preservação cultural efetivada.

Religiões de matriz africana

Embora encontrando novos modos neste Novo Mundo, esta religiosidade de tal forma apresentou-se como resistente e resiliente, que permanece ativa e, atualmente, atrai, para si, mais que descendentes de africanos, mesmo sem perder os fundamentos de seu pensamento

\footnotetext{
${ }^{11}$ Incluindo-se, no termo, todos os mestiços: mulatos, de branco e negro; mamelucos, de branco e índio; cafuzos, de negro com índio.
} 


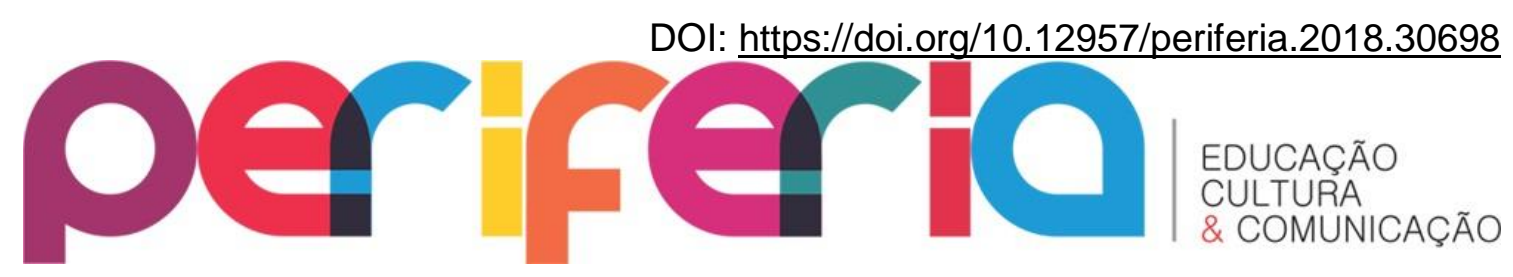

original.

Assim sendo, ela pode ser vista como guardiã segura da cultura que a origina, sobrevivendo, adaptada, não só ao processo escravista, mas, também, à intolerância oficial, que a enfrentou desde seus primeiros tempos.

Declarada ou não, explícita ou não, é fato que esta religiosidade ultrapassou todas as barreiras que lhe foram impostas, convivendo e sobrevivendo à catequese, que tentou transformá-la e eliminá-la; e o fez não como enfrentamento, mas encontrando formas de apresentar-se amalgamada, quer em complemento à religião oficial imposta, quer fundindo-se em formatos novos: do primeiro exemplo, o candomblé; do segundo, a umbanda; entre estes, farta gama de rituais, formas e nomes que, no entanto, podem ser todos remetidos aos modos africanos de pensar o sagrado; eis aí a gênese das já mencionadas irmandades e confrarias.

Iniciando a abordagem pelo candomblé, é preciso ressaltar que, embora o mesmo pensamento teológico parece universalizar-se enquanto África, cada grupo tem diversa ritualização: afinal, em África, a cada povo corresponde o próprio orixá, com seu ritual especializado.

Assim sendo e com isto em foco, entenda-se: candomblé, na diáspora, admite a religiosidade adotada tanto pelos jêge-nagô - que se voltam aos orixás - quanto pelos bantu que se volta aos ancestrais. Daí as diversas nações em que o candomblé se multiplica, na diáspora e, especialmente, no Brasil.

Quanto à umbanda ${ }^{12}$, ressalte-se: umbanda não é candomblé. Essa a primeira noção que qualquer estudioso das religiões de matrizes africanas precisa ter em mente, para continuar a pesquisar.

Isto porque, talvez, se mostre preciso retornar às crenças pré-colombianas para historicizá-la: conta-se que a tradição maia, quanto à criação do mundo, admite a existência de um só continente, centrado no que é, hoje, o planalto de Goiás onde, barro, teriam sido feitos os homens; daí a cor acobreada, significando a junção da terra com a água, vivificada pelo sopro divino.

\footnotetext{
12 Ver o verbete Zélio Fernandino de Moraes. Disponível em: <http:/pt.wikipedia.org/wiki/Zélio_Fernandino_de_Morais>. Acesso em: 25 fev. 2006.
} 


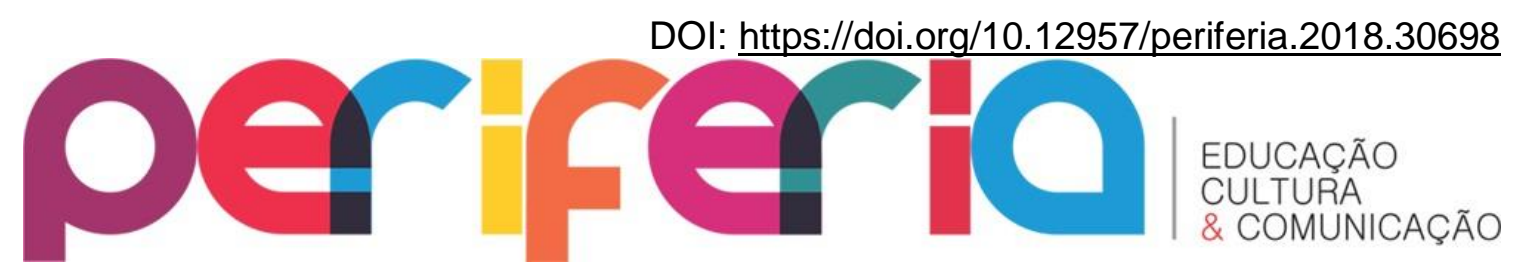

Desta lenda resta, aos tupi-guarani quando do descobrimento, a crença de que seu povo provinha de origem muito antiga, desenvolvendo-se, após o dilúvio universal, em determinada terra mítica, conhecida pelo nome Pindorama ${ }^{13}$ - que significa Terra das Palmeiras.

Como crença, acreditavam eles em um único deus, Tupã; mas reconheciam a existência da trindade sagrada, bem como a comunicação com seus antepassados através de ritos mediúnicos, em que estes espíritos interferiam na condução da comunidade.

O processo de catequese jesuítico utilizou-se desta formatação, transpondo valores católicos para os ritos encontrados e transformando lendas tupis em ensinamentos católicos, além de, codificando o idioma local, gestar a "língua geral" - o nheengatu.

Deste encontro cultural, restou a integração social e a primeira produção de mestiços locais - os atuais caboclos - que, já nascidos neste ambiente, admitiram este sincretismo como religião pura, completa; e sua.

Quanto ao encontro cultural, há que se destacar que, para o Brasil e nas demais colônias portuguesas, os "colonos" eram mais aventureiros que colonizadores: oriundos menos da nobreza que da camada inferior da Corte, onde transitavam cristãos-novos - judeus convertidos à força que, da situação de inferioridade social vivida em sua terra, preferiram a busca da aventura em Novo Mundo promissor, colocando-se ao largo das garras inquisitoriais; portanto, era povo com baixo nível de fé católica; por outras palavras, devotos do catolicismo popular.

Ora, também o catolicismo venera os mortos - seus santificados - assim como os tupis veneravam seus ancestrais; portanto, ambas as práticas encontraram correspondência mútua, sincretizando-se tão facilmente que produziram a mestiçagem, tanto física quanto cultural; é deste momento histórico que derivam religiões ainda híbridas e atuantes, das quais o jaré, a pajelança, o catimbó, o Santo Daime, bastam como exemplos.

É somente neste ponto que entram as religiões de matriz africana: especialmente da região de Angola, de onde provinha a grande maioria dos africanos escravizados nestes primeiros tempos da Colônia, já que o grande fluxo do Golfo da Guiné ganha força, apenas,

\footnotetext{
${ }^{13}$ Pindó = a gigantesca palmeira que permitiu o salvamento de Tamandaré e sua família, flutuando sobre as águas do dilúvio, assim como o Monte Ararat salvou Noé e sua família.
} 


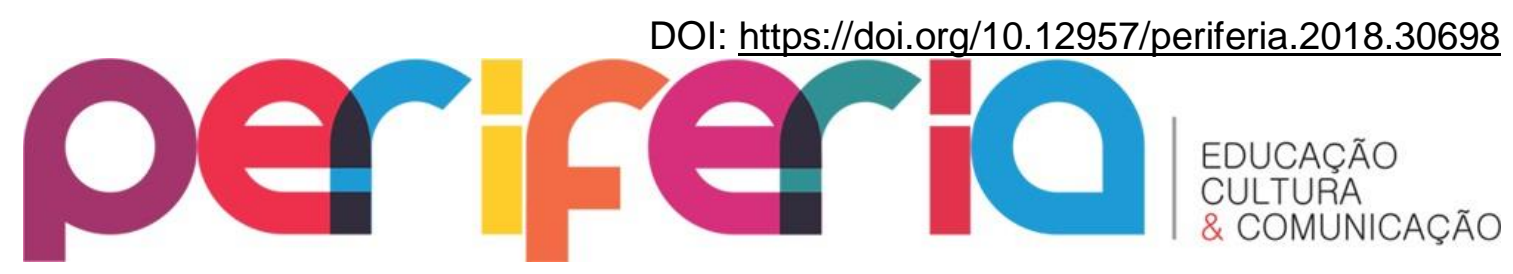

no último século da escravização.

O último ator deste quadro de sincretismos, e que deu, à crença anterior, a justificativa para sua aceitação pelos representantes do poder constituído, parece ter sido o espiritismo kardecista: é a partir dele que a umbanda adquire status de religião, pela concordância com a incorporação e a intervenção dos espíritos no mundo material; isto, porque o kardecismo explica, sob forma racional ${ }^{14}$ até, a comunicação entre espíritos e médiuns escolhidos: em outras palavras, a comunicação entre mortos e vivos, base de toda a crença anteriormente desenvolvida!

Portanto, se assim é, é com o aval de origem europeia, desenvolvido no início do séc. $\mathrm{XX}$, que a umbanda adquire status de religião.

Isto, a partir da manifestação espiritual, ocorrida em 15 de novembro de 1908 em Zélio Fernandino de Morais que, a partir de então, é considerado o primeiro médium da umbanda, que é brasileira; desta fonte deriva a umbanda em seu formato atual.

\section{Resumindo}

Poder-se-ia, ainda, prolongar este texto, abordando, por exemplo, a capoeira e as associações culturais, dentre outros modos; porém, é de se temer o gigantismo do mesmo, aparentemente inadequado para o meio em que se apresenta.

Porém, é importante, aqui, verificar a análise do confronto cultural desenvolvido por Gruzinski (2000), que assim pode ser resumido: o embate entre culturas literalmente diferentes, produz manifestações novas, via de regra estranhas e grotescas ao olhar do analista; de fato: o cruzamento entre manifestações diversas assentadas em culturas díspares, tende a produzir coisas novas que, ao longo do tempo, naturalizam-se. Como quer Exu.

Porém, há que se perceber que a cultura não comporta a visão monolítica e harmônica que, via de regra, o analista lhe impõe; isso porque "cultura", na verdade, é o amálgama de manifestações diversas, materializadas como feixes de tamanhos e dinâmicas desiguais; mas que convivem harmoniosamente, em determinado momento histórico, no espaço social analisado.

\footnotetext{
${ }^{14}$ Note-se que León Hippolyte Denizard Rivail - Allan Kardec - nasce em Lyon, França, em 03 de outubro de 1804, e falece em 31 de março de 1869; portanto, desenvolve toda a codificação kardecista sob influência do iluminismo francês.
} 


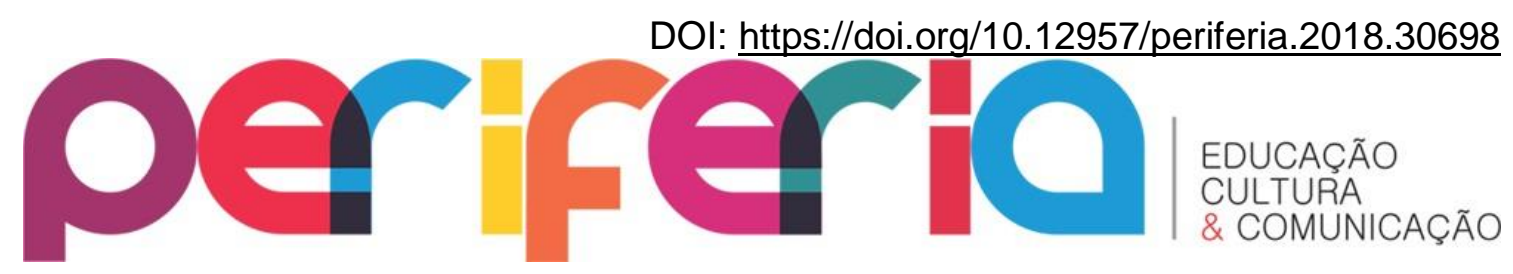

Cultura, enfim e de forma bastante resumida, pode ser entendida como as soluções que os grupos sociais conjuntamente desenvolvem para entender e conviver com o sagrado, seus pares, e a natureza; essa a razão pela qual, em determinado espaço e por algum tempo, as manifestações centram-se em alguns aspectos em detrimento de outros, que poderão até não ser compreendidos - o que pode causar repulsa no primeiro momento, embora seguida logo pela naturalização, tão bem captada por Gruzinski.

Assim sendo, há que se entender que a cultura é viva, dinâmica, constantemente sujeita à evolução histórica, à qual modifica, modificando-se e, em retorno, afetando a própria sociedade que, em consequência, deve readaptar-se aos novos modos; o que requer novas modificações. Exu que o diga!

Daí que não é possível admitir-se a voz comum da passividade negra frente ao processo escravista, o que, embora clamorosamente negado pelo matiz de nossa cultura atual, ainda vem apregoado por seus enfrentadores.

Porém, conforme palidamente pode ser visto aqui, o negro, tanto africano quanto escravodescendente, em nenhum momento se rendeu, apenas, à cultura que o escravizou: sempre procurou e encontrou formas de enfrentamento, pacífico ou não, insidiosas ou não, de tal forma que os termos "resistência" ou "tolerância" aplicados à movimentação cultural dos negros em terras do Novo Mundo, nada mais são que reducionismos inadequados.

Isto porque basta olhar para qualquer lado desta cultura atlanticotransposta para ver, acima e ao lado, uma figura negra que ri; mesmo que à socapa e disfarçadamente, é jocoso que expõe sua interpenetração insidiosa, que nenhuma belicidade eurocentrada foi, é, ou será capaz de impedir.

\section{REFERÊNCIAS}

ANTONIO BENTO (abolicionista). Verbete. Disponível em: <http://pt.wikipedia.org/wiki/Antônio_Bento_(abolicionista)>. Acesso em: 28 jun. 2007.

BARBOSA, Wilson do Nascimento. Recorrência Afro-Religiosa e Nova Mística in $A$ capoeira dura e a religião afro-brasileira, pp. 39-69. Palestra no Núcleo de Estudos Afrobrasileiros da Universidade Católica de São Paulo, 1996. Disponível em: < https://sites.google.com/site/dnbwilson/histriasocia >. Acesso em: 20 abr. 2007.

BASTIDE, Roger. As religiões africanas no Brasil. 3. ed. São Paulo: Pioneira, 1989. 


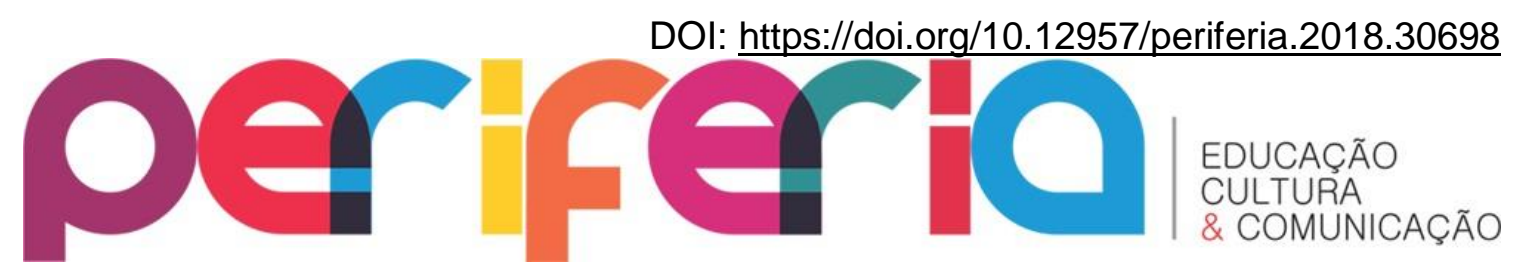

FREYRE, Gilberto. Casa grande e senzala. 34. ed. Rio de Janeiro: Record, 1998.

GRUZINSKI, Serge. O pensamento mestiço. São Paulo: Companhia das Letras, 2000.

LOPES, Nei. Enciclopédia brasileira da diáspora africana. São Paulo: Selo Negro, 2004.

MOVIMENTO DOS CAIFAZES. Verbete. Disponível em: <http://pt.wikipedia.org/wiki/Movimento_dos_Caifazes>>. Acesso em: 2 jul. 2007.

MOURA, Clóvis. História do negro brasileiro. São Paulo: Ática, 1989 (Princípios).

MUNANGA, Kabengele. Origem e histórico do quilombo na África. Revista USP, São Paulo, n.28, p. 56-63, dez./fev, 1995-1996.

; GOMES, Nilma Lino. O negro no Brasil de hoje. São Paulo: Global, 2006. (Coleção Para Entender).

QUINTÃO, Antonia Aparecida. Lá vem meu parente: as irmandades de pretos e pardos no Rio de Janeiro e em Pernambuco (Século XVIII). São Paulo: Anablume: Fapesp, 2002.

QUINTINO DE LACERDA. Verbete. Disponível em: < http://www.novomilenio.inf.br/santos/fotos028.htm>. Acesso em: 3 jul. 2007.

RIBEIRO, Darcy. O povo brasileiro. São Paulo: Companhia das Letras, 1995.

SANTOS, Marco Antonio dos. A polêmica carta da Princesa Isabel. Disponível em: <http://marconegro.blogspot.com.br/2006/05/polmica-carta-da-princesa-isabel.html>. Acesso em: 2 jul. 2007.

SILVA, Eduardo. As camélias do Leblon e a abolição da escravatura: uma investigação de história cultural. São Paulo: Companhia das Letras, 2003.

SLENES, Robert W. Na senzala, uma flor. Rio de Janeiro: Nova Fronteira, 1999.

TOLLENARE, L.F. $O$ eito $e$ a senzala. Disponível em: < http://www.jangadabrasil.com.br/maio45/of45050b.htm>. Acesso em: 23 jun. 2007.

ZELIO FERNANDINO DE MORAIS. Verbete. Disponível em: < http://pt.wikipedia.org/wiki/Zélio_Fernandino_de_Morais >. Acesso em: 25 jun. 2007. 